DOI: https://doi.org/10.33330/jurteksi.v6i2.417

Available online at http://jurnal.stmikroyal.ac.id/index.php/jurteksi

\title{
SISTEM INFORMASI REKAP BUKU ONLINE MENGGUNAKAN METODE WATERFALL
}

\author{
Andri Suryadi \\ Fakultas Sains dan Teknologi Program Studi Sistem Informasi, Universitas Terbuka \\ Email: andri.suryadi@ecampus.ut.ac.id
}

\begin{abstract}
The development of Information Technology in the field of education, a survey on the Use and Utilization of Information and Communication Technology was carried out on 4,014 schools in 34 provinces. Based on the level of education, elementary and equivalent as much as 64.55 percent, junior high school and equivalent as much as 19.22 percent and high school and equivalent as much as 16.23 percent. While the use of applications in the field of education is still felt to be lacking especially in rural schools so that there is a gap between urban schools and rural schools. This condition occurs in SMP PGRI Malangbong where the use of applications is still lacking. One example is in the recording of books in schools that are still manual which complicates operations in the school. The solution offered is to create an online book recapitulation system which is expected to be very useful for school operations. The online book recapitulation system was built using the waterfall method starting from the analysis, design, implementation, testing to maintenance stages.
\end{abstract}

Keywords: Book Information system; Book Schools

\begin{abstract}
Abstrak: Perkembangan Teknologi Informasi di bidang pendidikan, survei Penggunaan dan Pemanfaatan Teknologi Informasi dan Komunikasi dilakukan terhadap 4.014 sekolah yang tersebar di 34 provinsi. Berdasarkan jenjang pendidikan, SD dan sederajat sebanyak 64,55 persen, SMP dan sederajat sebanyak 19,22 persen dan SMA dan sederajat sebanyak 16,23 persen. Sedangkan penggunaan aplikasi dibidang pendidikan masih dirasa kurang terutama di sekolah-sekolah pedesaan sehingga terjadinya kesenjangan antara sekolah diperkotaan dan sekolah pedesaan. Kondisi tersebut terjadi pada SMP PGRI Malangbong dimana penggunaan aplikasi masih sangat kurang. Salah satu contohnya adalah dalam perekapan buku di sekolah yang masih bersifat manual yang menyulitkan operasional di sekolah tersebut. Solusi yang ditawarkan adalah dengan membuat sistem rekap buku online yang diharapkan sangat berguna bagi operasional sekolah. Sistem rekap buku online ini dibangun menggunakan metode waterfall mulai dari tahap analisis, desain, implementasi, pengujian sampai dengan pemeliharaan.
\end{abstract}

Kata Kunci: Buku Sekolah; Sistem Informasi Rekap Buku 
JURTEKSI (Jurnal Teknologi dan Sistem Informasi)

Vol. 6 No. 2, April 2020, hlm. $101-108$

DOI: https://doi.org/10.33330/jurteksi.v6i2.417

Available online at http://jurnal.stmikroyal.ac.id/index.php/jurteksi

\section{PENDAHULUAN}

Pada saat ini perkembangan teknologi informasi dapat dirasakan sangat cepat. Hal tersebut dapat dilihat dari beberapa negara yang berlombalomba untuk bersaing di bidang teknologi informasi [1], [2]. Tren teknologi informasi pada tahun 2019 seperti otomatisasi robot, Platform Keamanan Siber Berbasis Cloud, Infrastruktur Model End-to-End, Aplikasi Cerdas dan Big Data menjadi sebuah hal yang harus dikuasai oleh setiap orang [3]. Di bidang pendidikan, survei Penggunaan dan Pemanfaatan Teknologi Informasi dan Komunikasi dilakukan terhadap 4.014 sekolah yang tersebar di 34 provinsi. Berdasarkan jenjang pendidikan, SD dan sederajat sebanyak 64,55 persen, SMP dan sederajat sebanyak 19,22 persen dan SMA dan sederajat sebanyak 16,23 persen [4]. Sedangkan penggunaan aplikasi dibidang pendidikan masih dirasa kurang terutama di sekolah-sekolah pedesaan sehingga terjadinya kesenjangan antara sekolah diperkotaan dan sekolah pedesaan.

Kesenjangan tersebut terjadi karena adanya ketidaksamaan dalam akses pada teknologi informasi. Tidak meratanya pendidikan dan infrastruktur, serta perbedaan ekonomi menjadi batasan utama seseorang dalam mengakses teknologi informasi [4],[6],[7].

Pada masyarakat perkotaan dapat dilihat pada kondisi infrastruktur, tingkat pendidikan dan ekonomi yang lebih maju jika dibandingkan masyarakat pedesaan, sehingga pengetahuan, kemampuan dan kesempatan mereka dalam mendapatkan fasilitas teknologi lebih luas. Masyarakat pedesaan yang sebagian besar bermatapencaharian sebagai petani masih merasa sulit dalam mendapatkan akses terhadap teknologi pada setiap aktivitasnya sehingga kebanyakan mereka belum menyadari bahwa teknologi dapat mendukung pekerjaan mereka. Hal ini berbeda dengan masyarakat kota, dimana mereka lebih memiliki kesempatan terutama dalam pekerjaannya dengan memanfaatkan internet, sehingga mereka memiliki pengetahuan dan keterampilan lebih dalam penguasaan TIK [5],[8].

Dari sisi aplikasi sekolah diperkotaan cenderung lebih banyak menggunakan aplikasi yang dapat mendukung dalam menyelesaikan administrasi [9],[10], sedangkan sekolah-sekolah dipedesaan hal tersebut tidak didapatkan sehingga sekolah dipedesa-an cenderung ketinggal dibandingkan diperkotaan. Sebagai contoh pada sekolah-sekolah perkotaan, rekap data sekolah sudah dapat menggunakan aplikasi sehingga operasional pada sekolah tersebut sangat mudah dan mempercepat pengerjaan. Sedangkan disekolah pedesaan hal tersebut sangat sulit didapatkan.

Sebagai contoh hasil dari wawancara di SMP PGRI Malangbong yang terletak disebuah kecamatan yang berada di utara Kabupaten Garut, dibutuhkan sebuah aplikasi untuk dapat merekap data buku. Aplikasi tersebut sangat dibutuhkan mengingat banyaknya buku yang tidak tersimpan dengan baik. Buku-buku tersebut merupakan aset negara yang harus dipelihara sehingga pihak sekolah sangat kesulitan dalam mengendalikan arsip 
JURTEKSI (Jurnal Teknologi dan Sistem Informasi)

Vol. 6 No. 2, April 2020, hlm. $101-108$

DOI: https://doi.org/10.33330/jurteksi.v6i2.417

Available online at http://jurnal.stmikroyal.ac.id/index.php/jurteksi

buku tersebut. Pada saat ini proses penyimpanan buku masih bersifat manual sehingga membuat kesulitan petugas buku dalam memeliharanya. Pihak sekolah mengingkan sebuah aplikasi yang dapat mengelola buku dengan baik tetapi dapat dipantau laporan secara online supaya dapat memudahkan dalam operasionalnya. Berdasarkan data tersebut maka dibutuhkan sebuah aplikasi sistem informasi rekap buku online yang dapat memenuhi kebutuhan sekolah SMP PGRI Malangbong. Penelitian ini membangun sebuah sistem informasi rekap buku online menggunakan metode waterfall [5] yang diharapkan dari hasil penelitian ini dapat bermanfaat khususnya bagi yang akan menggunakannya.

\section{METODE}

Tahapan penelitian dalam Sistem Informasi rekap buku online ini dapat dilihat pada gambar 1 .

Tahapan penelitian yang telah digambarkan pada gambar 1 dapat jelaskan sebagai berikut:

1. Studi Literatur

Tahap pertama dalam penelitian ini adalah studi literature. Dalam studi literatur ini terdapat dua tahapan yaitu tentang sistem informasi perpustakaan dan model waterfall [8] sebagai perancangan perangkat lunak.

2. Perangkat Lunak Model Waterfall Pembangunan Sistem informasi perpustakaan ini menggunakan model waterfall. Model ini memiliki tahapannya diantaranya perancangan atau analisis sistem, desain sistem, implementasi, pengujian dan pemelliharaan. Dari pembangunan perangkat lunak ini menghasilkan kelas dari data latih kemudian akan diuji coba dengan data uji dari calon mahasiswa.

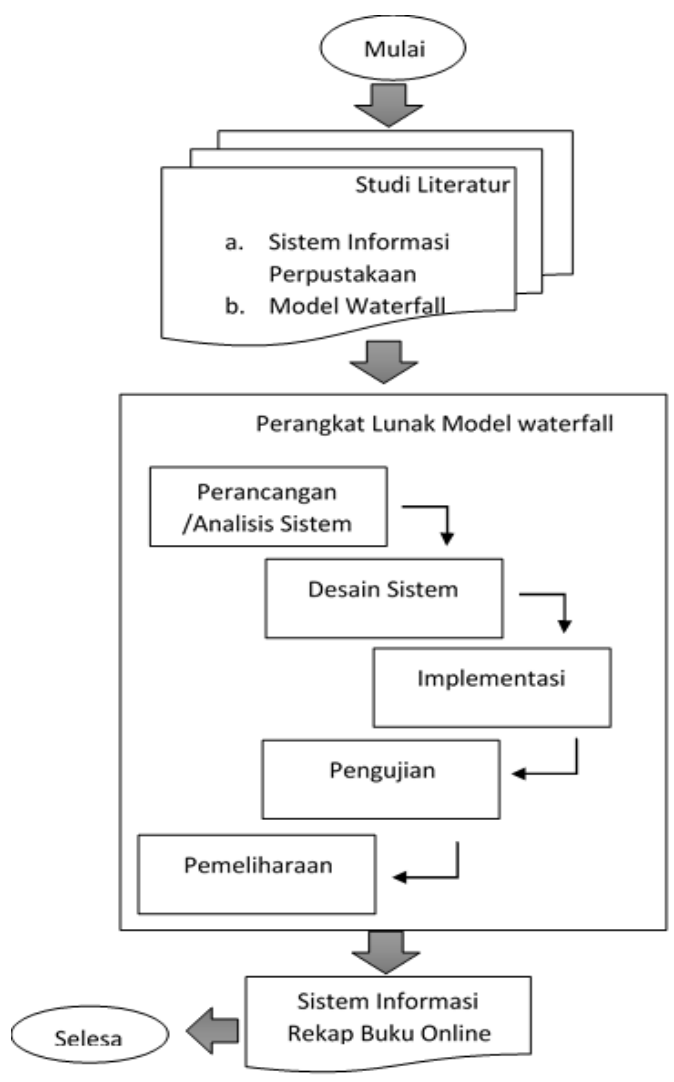

\section{Gambar 1. Alur Penelitian}

Penelitian ini dilakukan di sebuah di Sekolah Menengah Pertama (SMP) PGRI Malangbong yang terletak di Garut Utara provinsi Jawa Barat. Sedangkan jumlah responden yang terlibat dalam pembuatan sistem informasi rekap buku online ini sebanyak 4 orang dari pihak sekolah dan 10 orang siswa. 4 orang tersebut terdiri dari 1 orang kepala sekolah, 1 orang guru dan 2 orang tenaga perpustakaan. 
JURTEKSI (Jurnal Teknologi dan Sistem Informasi)

Vol. 6 No. 2, April 2020, hlm. $101-108$

DOI: https://doi.org/10.33330/jurteksi.v6i2.417

Available online at http://jurnal.stmikroyal.ac.id/index.php/jurteksi

\section{HASIL DAN PEMBAHASAN}

\section{Analisis Sistem}

Dari hasil wawancara yang telah dilakukan di SMP PGRI Malangbong, terdapat beberapa spesifikasi sistem rekap buku sebagai berikut:

1) Sistem rekap buku online merupakan sistem yang akan merekap buku, tamu, dan transaksi peminjaman buku

2) Pengguna yang terlibat dari sistem rekap buku ini adalah, pegawai sebagai administrator dan pengguna sebagai tamu.

3) Buku yang akan diinput adalah buku yang berada di sekolah

4) Pengguna sebagai tamu dapat tercatat di buku tamu jika mengunjungi perpustakaan dengan cara menginput sendiri data pengunjung.

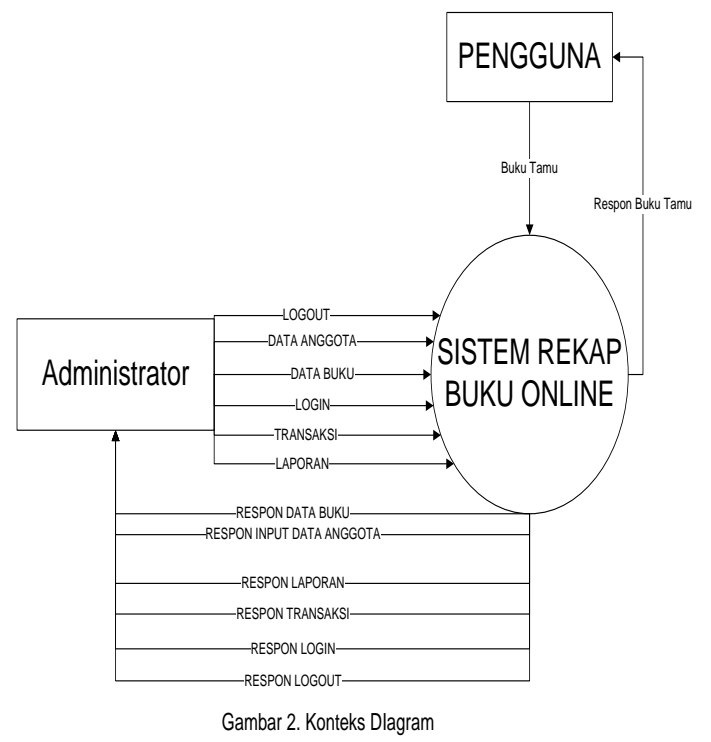

5) Pegawai sebagai administrator dapat melakukan aksi diantaranya:

a. Login sistem b. Memanipulasi Data buku

c. Memanipulasi Data Anggota

d. Melakukan transaksi

e. Melihat laporan

6). Aplikasi ini berbasis web sehingga dapat diakses dimana saja.

\section{Desain Sistem}

Langkah awal dalam pembuatan DFD adalah dengan membuat konteks diagram. Konteks diagram merupakan gambaran sistem secara keseluruhan yang didalamnya terlihat entitas luar yang berhubungan dengan sistem. Dari konteks diagram tersebut kemudian di breakdown menjadi DFD level 1. DFD level 1 terdiri dari proses-proses yang berlangsung dari konteks diagram. Dari DFD level 1 kemudian di breakdown kembali menjadi DFD level 2. DFD level 2 merupakan proses yang lebih detail lagi dari DFD level 1.

\section{DFD Level 0 / Konteks Diagram}

Dalam DFD level 0 ini sistem informasi rekap buku online, terdapat dua pelaku sistem yaitu admin dan anggota. Admin itu sendiri melakukan proses-proses sebagai berikut :

1. Proses Login

2. Proses Logout

3. Proses Manipulasi Data Buku

4. Proses Manipulasi Data Anggota

5. Proses Transaksi

6. Proses Melihat Laporan

Sedangkan pengguna atau tamu dapat menginput data tamu secara sendiri dan direspon oleh sistem.

\section{DFD Level 1}

Proses yang pertama yaitu login administrator. Seorang ad-ministrator dapat melakukan login pada sistem 
JURTEKSI (Jurnal Teknologi dan Sistem Informasi)

Vol. 6 No. 2, April 2020, hlm. $101-108$

DOI: https://doi.org/10.33330/jurteksi.v6i2.417

Available online at http://jurnal.stmikroyal.ac.id/index.php/jurteksi

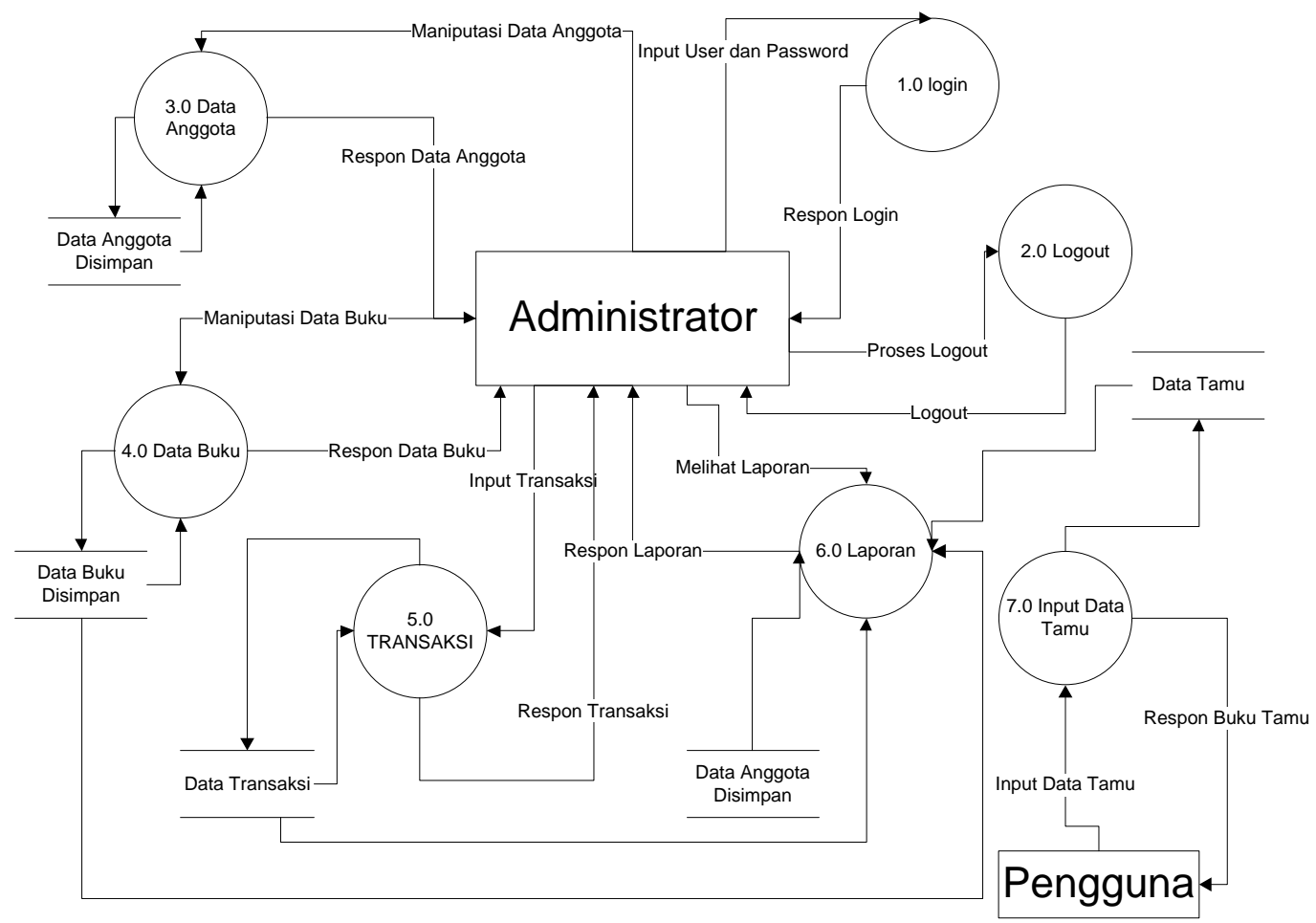

Gambar 3. DFD Level 1

buku online ini. Cara login administrator adalah dengan memasukan data login kemudian akan keluar pesan dan pindah ke halaman login. Kemudian proses administrator berikutnya adalah logout. Administrator dapat melakukan logout dengan cara menekan tombol logout kemudian administrator akan keluar dari halaman dashboard dan kembali kehalaman utama.

Selanjutnya proses berikutnya adalah data anggota. Seorang adminsitrator dapat memanipulasi data anggota sehingga data anggota pada sistem rekap buku online ini update.

Kemudian proses berikutnya adalah data buku. Sama seperti data anggota data buku dapat dimanipulasi dengan sehingga data buku yang ada di sekolah tersimpan secara update.

Selanjutnya administrator dapat melakukan proses transaksi. 
JURTEKSI (Jurnal Teknologi dan Sistem Informasi)

Vol. 6 No. 2, April 2020, hlm. $101-108$

DOI: https://doi.org/10.33330/jurteksi.v6i2.417

Available online at http://jurnal.stmikroyal.ac.id/index.php/jurteksi

sendiri khusus untuk tamu. Dengan adanya data tamu maka dapat dilihat siapa saja yang mengunjungi pada sistem rekap buku ini.

\section{Implementasi}

Pada tahap implementasi ini adalah tahapan dimana implementasi perancangan/desain menjadi sebuah aplikasi. Tahapan ini merupakan pembuatan hardcode/coding menggunakan bahasa pemograman web dan database. Hasil dari implementasi ini akan disajikan dalam bentuk tampilantampilan sebagai berikut:

a. Halaman Depan Login

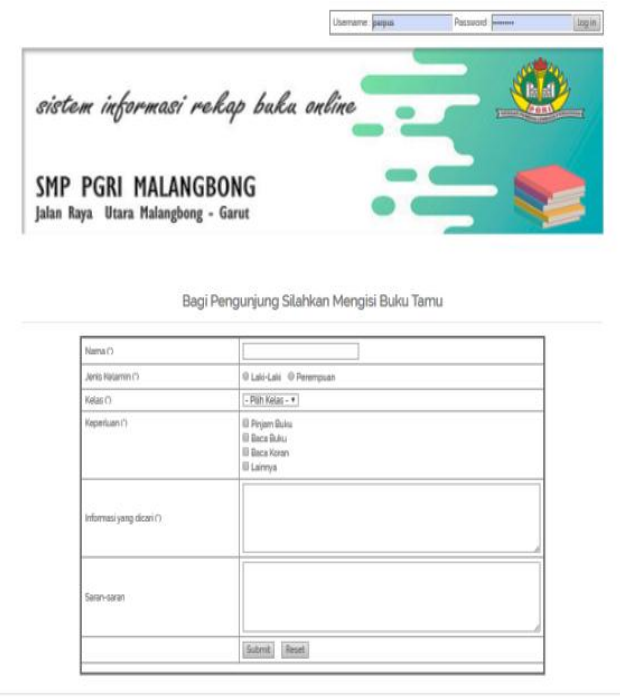

\section{Gambar 5. Tampilan Login}

Tampilan login merupakan tampilan depan yang pertama kali dilihat. Pada tampilan ini terdapat form login dan buku tamu. Buku tamu yang diinputkan adalah nama, jenis kelamin, kelas, keperluan, informasi yang dicari, saran-saran. Tamu dapat mengisi sendiri form buku tamu dan tidak melibatkan pegawai dalam pengisian datanya. b. Tampilan dashboard

Tampilan dashboard merupa-kan tampilan setelah login berhasil dilakukan. Tampilan dashboard terdiri dari tiga posisi header, samping kiri dan samping kanan. Header diisi sama dengan tampilan login yatu diisi dengan banner logo dan text. Posisi samping kiri diisi oleh menu-menu yang ada pada aplikasi yaitu menu home, transaksi, data buku, data anggota, laporan, edit user dan logout. Kemudian posisi kanan diisi oleh respon jika menu diklik oleh pengguna.

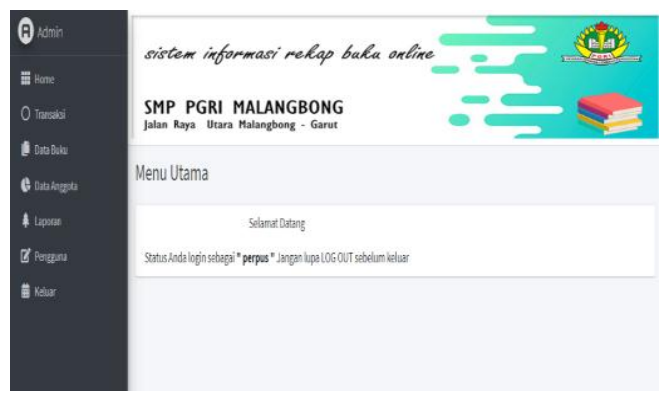

\section{Gambar 6. Tampilan Admin}

\section{Pengujian Sistem}

Pengujian menggunakan metode blackbox testing [11]. Blackbox testing merupakan pengujian yang dilihat dari fungsi yang berjalan pada aplikasi. Berikut rincian prosedur testing dan keberhasilan dalam pengujian.

\section{Pemeliharaan}

Sebelum pemeliharaan hal yang dilakukan adalah desain arsitektur sistem. Berikut gambaran desain arsitektur pada sistem rekap buku online ini.

Aplikasi disimpan pada server secara cloud yang dapat diakses secara online. Hal tersebut untuk memudah- 
Available online at http://jurnal.stmikroyal.ac.id/index.php/jurteksi

Tabel 1. Tabel Pengujian Blackbox

\begin{tabular}{lll}
\hline \multicolumn{1}{c}{ Menu } & \multicolumn{1}{c}{ Skenario pengujian } & \multicolumn{1}{c}{ Ket } \\
\hline 1. Login & $\begin{array}{l}\text { Memasukan Username dan Password } \\
\text { benar }\end{array}$ & Berhasil \\
\cline { 2 - 3 } & $\begin{array}{l}\text { Memasukan Username dan Password } \\
\text { salah }\end{array}$ & Respon Baik \\
\hline 2. Input Data Tamu & Memasukan Data Tamu benar & Berhasil \\
\cline { 2 - 3 } & Memasukan Data Tamu salah & Respon Baik \\
\hline 3. Transaksi & Lihat Transaksi & Berhasil \\
\cline { 2 - 3 } & Input Transaksi lengkap & Berhasil \\
\cline { 2 - 3 } & Input Transaksi tidak lengkap & Respon Baik \\
\cline { 2 - 3 } & Pengembalian Transaksi & Berhasil \\
\hline 4. Data Buku & Lihat Buku & Berhasil \\
\cline { 2 - 3 } & Memasukan Data Buku & Berhasil \\
\cline { 2 - 3 } & Edit Data Buku & Berhasil \\
\cline { 2 - 3 } & Hapus Data Buku & Berhasil \\
\hline 5. Data Anggota & Lihat Data Anggota & Berhasil \\
\hline 6. Laporan & Lihat Data Peminjaman & Berhasil \\
\hline 7. Edit User & Lihat User & Berhasil \\
\cline { 2 - 3 } & Memasukan Data User & Berhasil \\
\cline { 2 - 3 } & Edit Data User & Berhasil \\
\cline { 2 - 3 } & Hapus Data User & Perintah Logout \\
\hline 8. Logout & & \\
\hline
\end{tabular}

kan dalam pemeliharaan sistem karena keterbatasan tenaga IT pada sekolah SMP PGRI Malangbong. Dengan berbasis cloud maka baik pengguna maupun admin hanya membutuhkan akses internet saja untuk dapat menjalankan aplikasi sistem rekap buku online.

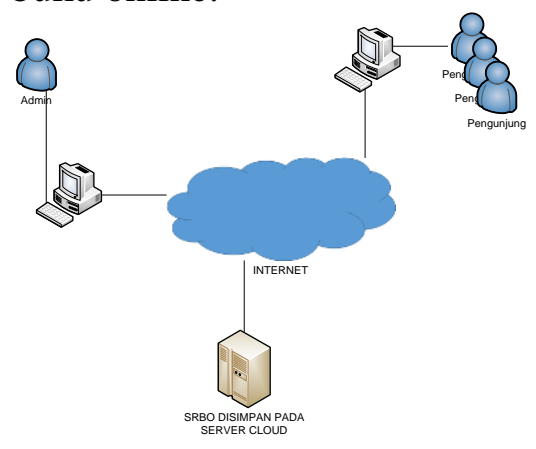

Gambar 7. Tampilan Arsitektur Sistem

\section{SIMPULAN}

Simpulan yang dapat diambil dari aplikasi sistem rekap buku online yang telah dibuat ini adalah aplikasi sistem rekap buku online diharapkan dapat membantu operasional rekap buku yang tadinya bersifat manual menjadi lebih terkomputerisasi. Selain itu aplikasi ini juga dapat memudahkan dalam proses pencarian data baik data buku, data pengguna dan laporan. Dari 8 menu yang telah dilakukan uji aplikasi $100 \%$ berhasil sesuai dengan yang diharapkan. 
DOI: https://doi.org/10.33330/jurteksi.v6i2.417

Available online at http://jurnal.stmikroyal.ac.id/index.php/jurteksi

\section{DAFTAR PUSTAKA}

[1] M. Ngafifi, "Kemajuan Teknologi dan Pola Hidup Manusia Dalam Perspektif Sosial Budaya”. Jurnal Pembangunan Pendidikan: Fondasi dan Aplikasi, vol. 2, no. 1, pp. 33-47, 2014. 2(1), 33-47. (2014).

[2] F. R. Rahim, D. S. Suherman, \& M. Murtiani, "Analisis Kompetensi Guru dalam Mempersiapkan Media Pembelajaran Berbasis Teknologi Informasi Era Revolusi Industri 4.0," Jurnal Eksakta Pendidikan," vol. 3 no. 2, pp. 133-141. 2019.

[3] A. Mahbub, "5 Tren Teknologi yang Diprediksi Cerah pada 2019," 2019, [online]. Retrieved from

https://tekno.tempo.co/read/1156 652/5-tren-teknologi-yangdiprediksi-cerah-pada2019?page_num $=1$.

[4] S.Tri, dan N. H. Atika, "Penggunaan dan Pemanfaatan Teknologi Informasi dan Komunikasi (P2TIK) Sektor Pendidikan 2018." BPSStatistics Indonesia. 2018.

[5] Y.Dewinta, "Kesenjangan Digital pada Pengembangan Master Tree Grower di Kabupaten Gunungkidul Yun Dewinta," 2018.

[6] G. M.Putra, N. Irawati, \& A. Prijuna, "Pelatihan Blog Sebagai Sarana Sarana Publikasi Pembelajaran Guru SMA Negeri 2 Kisaran," Jurdimas Royal, vo. 2 no. 2, pp. 143-150. 2019.

[7] D. S. Batubara, "Kompetensi
Teknologi Informasi dan Komunikasi Guru SD/MI (Potret, Faktor-faktor, dan Upaya

Meningkatkannya)," Muallimun a: Jurnal Madrasah Ibtidaiyah, vo. 3, no. 1, pp. 48-65, 2018.

[8] L. Suryati, "Strategi Pusat Pembelajaran Teknologi dan Internet (Broadband Learning Center) dalam Mengembangkan Kewarganegaraan Digital pada Masyarakat Kota Surabaya," Kajian Moral dan Kewarganegaraan, vol. 6, no. 3, 2018.

[9] N. Mayesti, A. Salam, \& R. Noviani, "Perpustakaan Umum Sebagai Sarana Literasi Informasi: Representasi dalam Film Indonesia," The 1st Int. Conf. on Language, Literature and Teaching, pp. 624-632. April, 2017.

[10] D. Yuzistin, D. F. Aji, \& P. D. A. Pamungkas, "Sistem Informasi Administrasi Siswa Berbasis Website Pada SMA Islam Putradarma Bekasi," Bina Insani Ict Journal, vol. 3, no. 1, pp. 253-268, 2016.

[11] R. S. Pressmann, "Software Quality Engineering: A Practitioner's Approach," vol. 9781118592. 2010. 